\title{
Prototype Sistem Irigasi Subak berbasis Fuzzy Logic Menggunakan Wireless Sensor Network
}

\author{
I Wayan Kayun Wardana ${ }^{1}$, I Made Oka Widyantara ${ }^{2}$, Ni Made Ary Esta Dewi Wirastuti ${ }^{3}$ \\ [Submission: 12-02-2020, Accepted: 17-12-2020]
}

\begin{abstract}
Utilization of Information Technology in local Irrigation system in Bali called 'Subak' is expected to be able to distribute water evenly to all agricultural needs. Later, there will be no excess or even lack of water, no arable or infertile in the agricultural land due to water and its also expected to be able to produce maximum agricultural production. This study uses sensors of Soil Moisture, Soil Temperature and Soil pH which are expected to control water requirements for agricultural land which are flowed automatically by the system from the reports received by the sensor and the server using the Wireless Sensor Network. Water distribution will be carried out by the system after receiving water demand from sensors embedded in agricultural land using fuzzy logic so that the shared water will be the same as the Subak irrigation system but more controlled, effective and efficient. This may lead to better level of soil fertility required by plants as well as increase the agricultural output . The use of the Internet of Thinks (IoT) in this study will produce information that is fast and can be accessed on the Internet by using SmartPhone media, PCs or other communication devices.
\end{abstract}

Intisari - Pemanfaatan Teknologi Informasi pada Irigasi Subak di Bali diharapkan mampu membagi air secara merata ke seluruh pertanian yang membutuhkannya, dengan demikian nantinya tidak ada lahan pertanian yang kelebihan air ataupun kekurangan air, tidak ada lahan pertanian yang subur atau kurang subur karena faktor air dengan hasil yang diharapkan mampu menghasilkan produksi pertanian yang maksimal. Penelitian ini menggunakan sensor Kelembaban Tanah, Suhu Tanah dan $\mathrm{pH}$ tanah yang diharapkan mampu mengontrol kebutuhan air untuk lahan pertanian yang dialiri secara otomatis oleh sistem dari hasil laporan yang diterima sensor dan diterima server dengan menggunakan Wireless Sensor Network. Pembagian air akan dilakukan sistem setelah menerima permintaan kebutuhan air dari sensor yang tertanam di lahan pertanian dengan menggunakan logika fuzzy sehingga pebagian air sama dengan Sistem pengairan Subak di Bali namun lebih terkontrol, efektip dan efisien sehingga tingkat kesuburan tanah yang diperlukan tanaman akan mampu meningkatkan hasil pertanian. Penggunaan Internet of Thinks (IoT) dalam penelitian ini akan menghasilkan informasi yang cepat dan dapat diakses dari Internet menggunakan media SmartPhone, PC atau perangkat komunikasi lainnya.

Kata Kunci- Subak, Sensor, Kelembaban, suhu, pH, Wireless Sensor Netowrk, Internet of Thinks, IoT, Arduino

${ }^{1}$ Mahasiswa,Program Studi Magister Teknik Elektro, Fakultas Teknik, Universitas Udayana, Jln. Kampus Bukit Jimbaran 80361 INDONESIA (telp: 081353360000; e-mail: yanayun@gmail.com)

2, 3 Dosen, Program Studi Magister Teknik Elektro, Fakultas Teknik, Universitas Udayana, Jln. Jalan Kampus Bukit Jimbaran 80361 INDONESIA (telp: 0361-703315; fax: 0361-4321; e-mail: oka.widyantara@unud.ac.id,dewi.wirastuti@ee.unud.ac.id

I Wayan Kayun Wardana: Prototype Sistem Irigasi Subak.....

\section{PENDAHULUAN}

Faktor yang membuat tinggi rendahnya temperatur tanah salah satunya yaitu terdapat dari faktor luar antara lain radiasi matahari, awan, curah hujan, kecepatan angindan kelembaban udara. Sedangkan untuk faktor dalam meliputi faktor tanah yang meilupti struktur tanah, kadar air tanah, kandungan bahan organik, $\mathrm{pH}$ tanah dan warna tanah. Makin tinggi suhu maka semakin cepat pematangan pada tanaman [1]. Kajian Kelembaban Tanah dan Kebutuhan air beberapa Varietas Hibrida DR Unpad pada kelembaban yang dipertahankan $90 \%$ kapasitas lapang, tanaman membutuhkan air paling tinggi yaitu $345.45 \mathrm{~mm} / \mathrm{musim}$ dan memperlihatkan pertumbuhan dan hasil tanaman paling baik, serta efisiensi penggunaan air paling tinggi yaitu $1.83 \mathrm{~g} / \mathrm{L}$. [2].

Proses masuknya aliran air ke dalam tanah dipengaruhi beberapa faktor, antara lain, tekstur dan struktur tanah, persediaan air awal (kelembaban awal), kegiatan biologi dan unsur organik, jenis dan kedalaman tanah, dan tumbuhan bawah atau tajuk penutup tanah lainnya [3]. Tanah remah akan memberikan kapasitas aliran air lebih besar dari tanah liat. Tanah dengan pori-pori jenuh air mempunyai kapasitas lebih kecil dibandingkan tanah dalam keadaan kering.

Temperatur tanah dan kelembaban tanah mampu mempengaruhi nilai $\mathrm{pH}$ tanah di berbagai umur tanaman di perkebunan jambu biji varietas Kristal[4]. Peralatan sensor yang digunakan menggunakan energi yang sangat rendah dengan hanya menggunakan baterei 6-7Volt untuk lahan pertanian luas dan tidak ada aliran listrik. Masing-masing Sensor terhubung menggunakan Wireless Sensor Network ke pusat kendali berupa server yang akan mengolah data dan mengirimkan perintah ke peralatan untuk membuka tutup keran air sesuai dengan data yang dikirimkan ke server sampai kebutuhan air terpenuhi dari hasil sensor yang diterima server. Node sensor biasanya mampu mendeteksi parameter lingkungan seperti tingkat kelembaban, suhu, kelembaban karena kemampuan pemrosesan dan komunikasi.WSN dibentuk dengan menggunakan jenis-jenis node sensor seperti ini, WSN dapat mempertahankan untuk operasi normal, penghematan energi sangat penting dan menantang masalah untuk sensor node. Untuk jaringan berskala besar, hal ini lebih penting karena sensor dalam jenis jaringan ini berpartisipasi dalam lebih banyak lalu lintas dan karenanya, mengurangi energi sangat cepat [5].

Manfaat penelitian yang akan didapat dalam penelitian ini adalah kebutuhan air yang dialirkan ke lahan pertanian terkontrol, efektik dan efisien untuk tumbuh kembang tanaman, Sistem kontrol air otomatis tanpa campur tangan petani, pembagian air merata ke lahan pertanian yang

p-ISSN: 1693-2951;e-ISSN: 2503-2372 
membutuhkan pengairan sesuai dengan aturan Irigasi Subak yang ada di Bali dan hasil pertanian meningkat dengan menerapkan kontrol kelembaban tanah, suhu dan $\mathrm{pH}$ sesuai jenis tanaman.

\section{TINJAUAN MUTAKHIR}

Subak merupakan organisasi pertanian di Bali, salah satu yang terpenting dalam Subak adalah sistem irigasi air yang terbagi secara merata, namun sering terjadi ketidakadilan di lapangan yang menyebabkan terjadinya pergesekan antara anggota Subak dengan sistem pembagian air. Melihat kondisi tersebut, maka penelitian tentang Prototype Sistem Irigasi Subak berbasis Fuzzy Logic menggunakan Wireless Sensor Network menarik untuk dijadikan objek penelitian. Adapun penelitian-penelitian yang telah dilakukan berkaitan dengan hal tersebut, antara lain:

1. Penelitian yang dilakukan Garcia Pauca,dkk tahun 2015 dengan judul Decision Support for Smart Irrigation by Means of Wireless Distributed Sensor menggunakan sumber data sensor suhu dengan metode fuzzy logic menghasilkan kesimpulan Irigasi lebih banyak terjadi pada musim panas dan lebih sedikit di musim dingin, sensor suhu memberikan hasil lebih banyak dimusim panas[6] ditunjukan pada Gambar 1 dan Gambar 2.

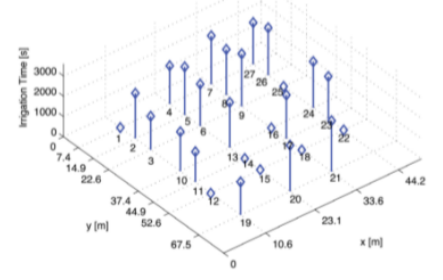

Gambar 1: Irigasi selama musim panas.

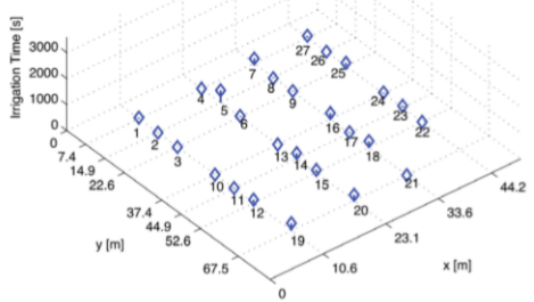

Gambar 2: Irigasi selama musim dingin.

2. Penelitian yang dilakukan Yousef E.M. Hamouda, dkk tahun 2017 dengan judul Smart Irrigation Decision support based on Fuzzy logic using wireless sensor network[7] dengan hasil penelitian adalah Waktu untuk irigasi menghasilkan waktu berbeda untuk kelembaban dan suhu seperti ditampilkan di Gambar 3.

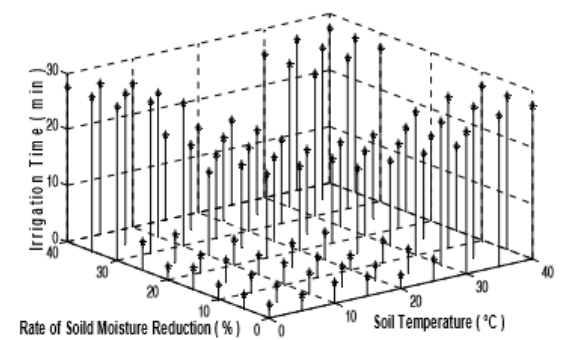

Gambar 3: Waktu untuk irigasi dengan Kelembaban dan temperature tanah.

3. Penelitian Benis, dkk tahun 2015 dengan judul Drip Irrigation sistem using wireless sensor network[8] yang menggunakan network simulator untuk mengolah data suhu, kelembaban dan tekanan menghasilkan performance yang baik dari delay, PDR untuk traffic yang diprioritaskan seperti ditampilkan Gambar 4 dan Gambar 5 .

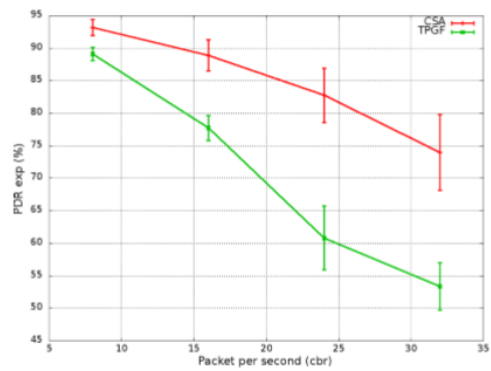

Gambar 4: Rata-Rata PDR dari prioritas traffic dengan packet per detik.

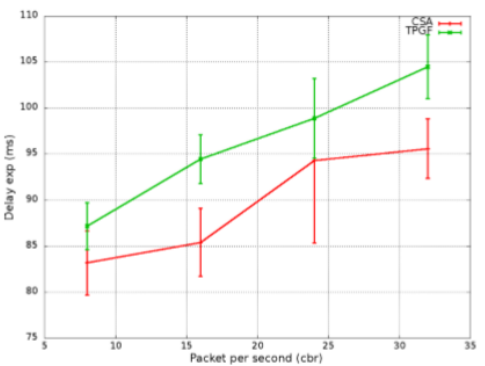

Gambar 5: Rata-Rata Delay dari prioritas traffic dengan packet per detik.

4. Penelitian yang dilakukan Putu Agus Fredy Satya Dharma, dkk tahun 2015 dengan judul Prototype Pemantauan Kadar air atau kelembaban pada tanah menggunakan Arduino dan Protokol Zigbee/IEEE 802.15.3 pada Platform M2M[11] menghasilkan informasi kekurangan air ditandai dengan penurunan nilai kelembaban air yang kurang dari 300, sedangkan kelebihan air ditandai dengan peningkatan nilai kelembaban air yang melebihi 600. Perbedaan nilai kelembaban yang dihasilkan pada jarak 5-15 meter dan 20-30 meter disebabkan karena adanya perbedaan kecepatan tanaman menyerap air yang ada pada tanah sehingga tanah pada 5-15 meter lebih cepat kering.

5. Penelitian Ananta Wijaya, dkk tahun 2016 dengan judul Design Model of Subak Smart Irrigation menggunakan 
data temperature tanah sebagi model simulasi irigasi yang akan memberikan perintah ke actuator untuk membuka tutup saluran air[9].

6. Penelitian Achmad Jufri, dkk tahun 2017 dengan judul Rancang Bangun Alat Ukur Suhu, Kelembaban, dan $\mathrm{pH}$ pada Tanah Berbasis Mikrokontroler ATMega328P menghasilkan bahwa hasil pengukuran alat standard dan alat buatan hampir sama dapat ditampilkan pada Gambar 6.[10]

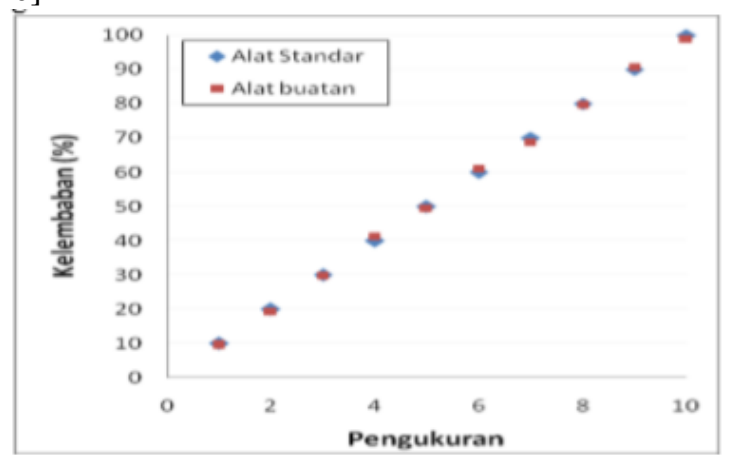

Gambar .6 Hasil pengukuran alat standard an alat buatan.

Melihat hasil penelitian di atas belum ada yang membahas atau meneliti mengenai Sistem Irigasi yang berbasis pada Subak di Bali dengan menggunakan model pembagian irigasi air sesuai tata cara pembagian air dalam ketentuan Subak di Bali dengan Irigasi yang menggunakan kontrol kelembaban tanah, $\mathrm{pH}$ tanah dan temperature tanah.

\section{MeTODELOGI}

Rancangan penelitian ini adalah sebuah langkah dalam merealisasikan sistem irigasi subak berbasis Wireless Sensor Network. Model perancangan penelitian ini akan mengadaptasi Smart Irrigation Decision Support baed on Fuzzy Logic using Wireless Sensor Network olehYousef E. M. Hamouda tahun 2017. Penelitian ini menggunakan Sensor Kelembabantanah, Sensor Suhu Tanah, Sensor PH tanah, Arduiono Uno,Raspberry Pi, dan Kran air otomatis sebagai kontrol untuk mengendalikan peralatan yang akan digunakan untuk penelitian ini[7]

Data yang digunakan dalam penelitian ini diambil dari sensor di lahan pertanian yang dikirimkan menggunakan Wireless Sensor Network melalui Router dan diproses di server. Data yang dikirim sensor setiap 5 menit ke server dan dijadikan pengambilan keputusan untuk melakukan buka tutup kran irigasi. Data yang diperoleh juga digunakan untuk membagi irigasi air kelahan pertanian yang membutuhkan melalui data yang diterima dari flow meter dan permintaan irigasi yang dikirimkan sensor di lahan pertanian, serta artikel jurnal, dan referensi buku yang menunjang analisa selama penelitian.

\section{HASIL DAN PEMBAHASAN}

Data yang dikirimkan sensor pada Node Sensor yang dikirim tiap 15 Menit mulai jam 8 pagi sampai jam 8 malam dapat dilihat pada Tabel dibawah. Melihat data tersebut, sensor suhu mengalami peningkatan mulai jam 12 siang sampai jam 3 sore dari suhu paling rendah $27^{\circ} \mathrm{C}$ sampai $35^{\circ} \mathrm{C}$, sedangkan kelembaban diatas 700 disebabkan tanah masih dalam keadaan basah karena diguyur hujan semalaman. Sedangkan $\mathrm{pH}$ tanah tidak banyak mengalami perubahan.

TABEL I

SENSOR NODE 3

\begin{tabular}{|c|c|c|c|c|c|c|c|}
\hline \multirow{2}{*}{$\frac{\mid \text { id } \quad \mid \mathrm{tg}}{|13541|}$} & \multicolumn{7}{|c|}{$\mid$ node | data_id | moisture | temperature $|\mathrm{ph}|$ status $\mid$} \\
\hline & | 2018-12-04 20:00:37| & $3 \mid$ & 49 & $708 \mid$ & $27 \mid$ & $7.23 \mid$ & $0 \mid$ \\
\hline | 13511| & $\mid$ & $3 \mid$ & 48 & 708 & 27 & 7.42 & 0 \\
\hline 13482 & | 2018-12-04 19:31:35 & $3 i$ & $47 \mid$ & 708 & 27 & $7.34 \mid$ & $0 \mid$ \\
\hline 13453 & | 2018-12-04 19:17:04 & $3 \mid$ & 46 & $707 \mid$ & 27 & $7.17 \mid$ & $0 \mid$ \\
\hline | $13424 \mid$ & | 2018-12-04 19:02:33 & $3 \mid$ & 45 & 708 & 28 & 7.35 & 0 \\
\hline | $13394 \mid$ & | 2018-12-04 18:48:02 | & $3 \mid$ & 44 & 708 & 28 & $7.38 \mid$ & $0 \mid$ \\
\hline | $13365 \mid$ & | 2018-12-04 18:33:31 | & $3 i$ & $43 \mid$ & 708 & 28 & $7.37 \mid$ & 0 \\
\hline | 13337| & | 2018-12-04 18:19:00 & $3 \mid$ & $42 i$ & $708 \mid$ & 28 & $7.44 \mid$ & $0 \mid$ \\
\hline 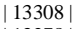 & | 2018-12-04 18:04:29 & $3 \mid$ & $41 \mid$ & 708 & 28 & $7.22 \mid$ & $0 \mid$ \\
\hline | 13278 | & | 2018-12-04 17:49:58 & $3 \mid$ & $40 \mid$ & $708 \mid$ & 28 & $7.26 \mid$ & $0 \mid$ \\
\hline | 13249 | & | 2018-12-04 17:35:26 & $3 \mid$ & $39 \mid$ & $709 \mid$ & $29 \mid$ & $7.45 \mid$ & $0 \mid$ \\
\hline | $13220 \mid$ & | 2018-12-04 17:20:55 & $3 \mid$ & 381 & 710 & $29 \mid$ & $7.38 \mid$ & $0 \mid$ \\
\hline | 13191| & | 2018-12-04 17:06:24 & $3 \mid$ & $37 \mid$ & 710 & 29 & 7.34 & 0 \\
\hline | $13161 \mid$ & | 2018-12-04 16:51:53| & $3 \mid$ & $36 \mid$ & 710 & $29 \mid$ & $7.25 \mid$ & $0 \mid$ \\
\hline | 13132| & | 2018-12-04 16:37:22 | & $3 \mid$ & $35 \mid$ & 710 & $29 \mid$ & $7.37 \mid$ & $0 \mid$ \\
\hline | $13104 \mid$ & | 2018-12-04 16:22:51 & $3 \mid$ & $34 \mid$ & 711 & $29 \mid$ & $7.16 \mid$ & $0 \mid$ \\
\hline | 13075 & | 2018-12-04 16:08:19 & $3 i$ & $33 \mid$ & $711 \mid$ & 29 & $7.23 \mid$ & 0 \\
\hline$|13045|$ & | 2018-12-04 15:53:48 & $3 \mid$ & 32 & 711 & 30 & 7.38 & $0 \mid$ \\
\hline | 13016| & | 2018-12-04 15:39:17 & $3 i$ & 31 & 712 & 31 & $7.42 \mid$ & 0 \\
\hline | 12987| & | 2018-12-04 15:24:46| & $3 i$ & 30 & $714 \mid$ & 32 & 7.36 & 0 \\
\hline | 12958 & | 2018-12-04 15:10:15 & $3 \mid$ & 29 & $717 \mid$ & 33 & $7.27 \mid$ & $0 \mid$ \\
\hline | $12928 \mid$ & | 2018-12-04 14:55:43 & $3 \mid$ & 28 & 723 & 35 & 7.35 & 0 \\
\hline | 12899 | & | 2018-12-04 14:41:12 | & $3 \mid$ & $27 \mid$ & 730 & 35 & $\mid 7.18$ & 0 \\
\hline | $12870 \mid$ & | 2018-12-04 14:26:41 | & $3 \mid$ & $26 \mid$ & $732 \mid$ & $35 i$ & $|7.31|$ & $0 \mid$ \\
\hline | $12842 \mid$ & | 2018-12-04 14:12:10 & $3 \mid$ & 25 & 733 & 35 & | $7.4 \mid$ & $0 \mid$ \\
\hline$|12812|$ & | 2018-12-04 13:57:39| & $3 \mid$ & $24 \mid$ & $736 \mid$ & $34 \mid$ & | $7.43 \mid$ & $0 \mid$ \\
\hline | 12783 | & | 2018-12-04 13:43:08 & $3 \mid$ & $23 \mid$ & $733 \mid$ & 33 & $|7.33|$ & 0 \\
\hline | $12754 \mid$ & | 2018-12-04 13:28:36 & $3 \mid$ & 22 & 728 & 33 & $|7.36|$ & 0 \\
\hline$|12725|$ & | 2018-12-04 13:14:05| & $3 \mid$ & 21 & $727 \mid$ & 31 & $|7.28|$ & $0 \mid$ \\
\hline | $12695 \mid$ & | 2018-12-04 12:59:34| & $3 \mid$ & $20 \mid$ & $723 \mid$ & 32 & $|7.17|$ & $0 \mid$ \\
\hline | 12666 | & | 2018-12-04 12:45:03 & $3 i$ & 19 & $723 \mid$ & 32 & $|7.27|$ & 0 \\
\hline | 12637| & $\mid$ 2018-12-04 12:30:32 | & $3 \mid$ & 18 & 723 & 34 & $|7.15|$ & $0 \mid$ \\
\hline | 12609 & | 2018-12-04 12:16:00 | & $3 \mid$ & $17 \mid$ & $727 \mid$ & 35 & $|7.35|$ & $0 \mid$ \\
\hline | $12579 \mid$ & | 2018-12-04 12:01:28 & $3 \mid$ & $16 \mid$ & $735 \mid$ & $33 i$ & | $7.31 \mid$ & $0 \mid$ \\
\hline | $12550 \mid$ & | 2018-12-04 11:46:57 & $3 \mid$ & $15 \mid$ & $729 \mid$ & 31 & | $7.17 \mid$ & $0 \mid$ \\
\hline |12521| & | 2018-12-04 11:32:26 | & $3 \mid$ & $14 \mid$ & $717 \mid$ & 31 & $|7.16|$ & $0 \mid$ \\
\hline | 12492 | & | 2018-12-04 11:17:55| & $3 \mid$ & $13 \mid$ & $718 \mid$ & $30 \mid$ & | $7.4 \mid$ & $0 \mid$ \\
\hline$|12462|$ & | 2018-12-04 11:03:24| & $3 \mid$ & 12 & $717 \mid$ & 30 & |7.31 & 0 \\
\hline | 12433 | & | 2018-12-04 10:48:53 & $3 \mid$ & $11 \mid$ & $716 \mid$ & $30 i$ & $|7.27|$ & $0 \mid$ \\
\hline | $12404 \mid$ & | 2018-12-04 10:34:21 & $3 i$ & $10 \mid$ & $719 \mid$ & $29 \mid$ & $|7.43|$ & $0 \mid$ \\
\hline | 12375 & | 2018-12-04 10:19:51 & $3 \mid$ & $9 \mid$ & $718 \mid$ & 28 & 7.35 & 0 \\
\hline$|12346|$ & | 2018-12-04 10:05:20 & $3 \mid$ & $8 \mid$ & 721 & $28 \mid 7$ & 7.35 & $0 \mid$ \\
\hline$|12317|$ & | 2018-12-04 09:50:49 & $3 i$ & $7 \mid$ & $714 \mid$ & $29 \mid$ & $7.16 \mid$ & $0 \mid$ \\
\hline $\mid 12288$ & | 2018-12-04 09:36:17 & $3 i$ & $6 \mid$ & 718 & 30 & $7.22 i$ & 0 \\
\hline $\mid 12259$ & | 2018-12-04 09:21:46 & $3 i$ & $5 \mid$ & $723 \mid$ & 29 & 7.31 & 0 \\
\hline $\mid 12229$ & | 2018-12-04 09:07:15 & $3 i$ & $4 \mid$ & 724 & 28 & 7.29 & 0 \\
\hline$|12200|$ & | 2018-12-04 08:52:44 | & $3 i$ & $3 \mid$ & $729 \mid$ & $27 \mid$ & $7.38 \mid$ & $0 \mid$ \\
\hline
\end{tabular}

Node Sensor penerima akan menentukan tindakan apakah akan membuka keran Air atau menutupnya dari datadata yang diterima dari Node Sensor pengirim dan mengolahnya menggunakan Fuzzy Logic, Data yang diterima Node Sensor Penerima dapat dilihat pada Gambar 7.

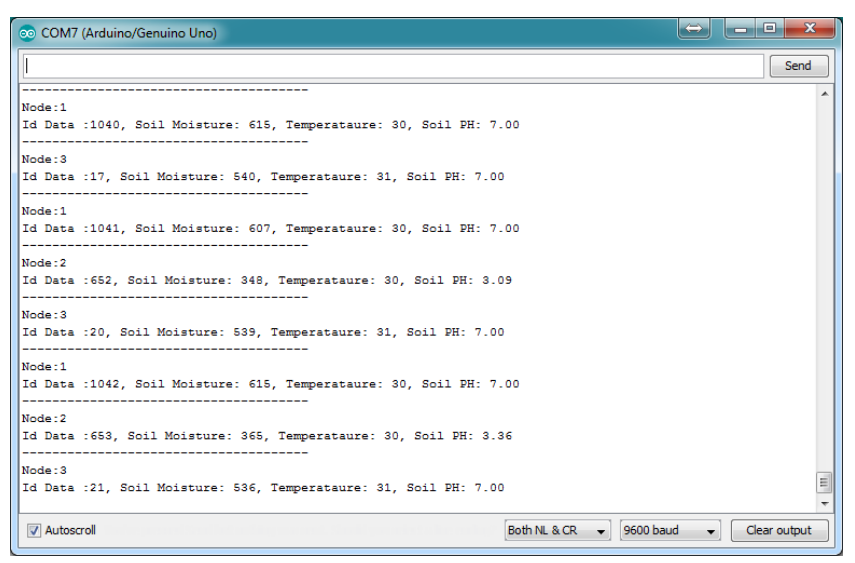

p-ISSN:1693-2951; e-ISSN: 2503-2327 
Gambar 7: Hasil penerimaan sensor dari masing-masing Node di Node Sensor penerima.

Penghitungan prosentasi pembagian air untuk petani disesuaikan dengan jumlah bibit yang ditanam dari masingmasing petani dapat dilihat pada tabel II.

TABEL II

PENGHITUNGAN PROSENTASE PEMBAGIAN AIR SESUAI DENGAN JUMLAH BIBIT SETIAP KILOGRRAM DARI PETANI

\begin{tabular}{|l|c|c|c|c|c|}
\hline & $\begin{array}{c}\text { Jumlah } \\
\text { Bibit /kg }\end{array}$ & $\begin{array}{c}\text { 3 Node } \\
\text { Sensor } \\
\text { Aktip }\end{array}$ & $\begin{array}{c}\text { 2 Node } \\
\text { Sensor } \\
\text { A \& B } \\
\text { Aktip }\end{array}$ & $\begin{array}{c}\text { 2 Node } \\
\text { Sensor } \\
\text { B \& C } \\
\text { Aktip }\end{array}$ & $\begin{array}{c}\text { 2 Node } \\
\text { Sensor } \\
\text { A \& C } \\
\text { Aktip }\end{array}$ \\
\hline $\begin{array}{l}\text { Petani } \\
\text { A }\end{array}$ & 25 & $12.50 \%$ & $25.00 \%$ & & $20.00 \%$ \\
\hline $\begin{array}{l}\text { Petani } \\
\text { B }\end{array}$ & 75 & $37.50 \%$ & $75.00 \%$ & $42.86 \%$ & \\
\hline $\begin{array}{l}\text { Petani } \\
\text { C }\end{array}$ & 100 & $50.00 \%$ & & $57.14 \%$ & $80.00 \%$ \\
\hline & $\begin{array}{l}\text { Jumlah } \\
\text { Prosentase }\end{array}$ & $\mathbf{1 0 0 \%}$ & $\mathbf{1 0 0 \%}$ & $\mathbf{1 0 0 \%}$ & $\mathbf{1 0 0 \%}$ \\
\hline
\end{tabular}

Air yang disalurkan dalam penelitian ini sebesar 1 Liter $(1000 \mathrm{~mL})$ yang dibagi ke masing-masing Petani dan disesuaikan dengan aturan Subak. Sensor akan berhenti mengalirkan air bila air yang dialirkan ke semua lahan telah mencapai $1000 \mathrm{~mL}$ dan memeriksa kembali kondisi pengiriman data dari masing-masing Node Sensor, bila Node Sensor masih memerlukan air maka akan kembali dialirkan air ke Lahan yang memerlukan dengan jumlah $1000 \mathrm{~mL}$.

Semua sensor yang ada di masing-masing node bekerja terus menerus. Apabila lebih dari satu node memenuhi kriteria seperti Suhu Naik, Kelembaban Turun atau pH naik maka secara otomatis membuka keran air dan waterflow menghitung debit air yang dikeluarkan, Akan tetapi bila hanya 1 node memenuhi kreteria maka waterflow mengabaikan penghitungan debit air sampai lahan tidak memerlukan lagi air dan water valve dimatikan secara otomatis. Pada penelitian ini untuk mengaliri lahan seluas 2x2 Meter diperlukan pengisian air antara 1-2 menit sampai sensor suhu mendeteksi penurunan suhu, mendeteksi kelembaban naik atau $\mathrm{pH}$ turun sesuai dengan nilai yang ditentukan. Gambar dari Flowchart pembagian air sesuai dengan aturan Subak dapat dilihat pada Gambar 8.

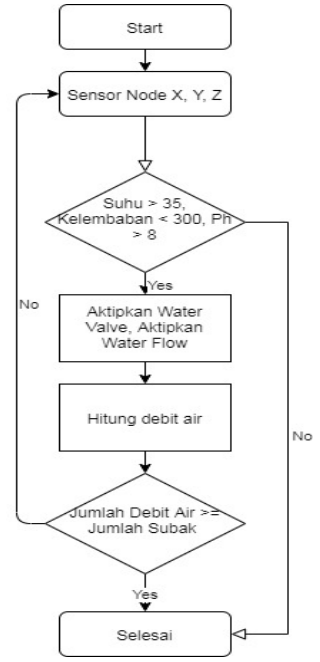

Gambar 8: Flowchart pembagian air berdasarkan aturan Subak.

Cara kerja Wireless Sensor Network mulai pemeriksaan keadaan tanah sampai menghasilkan informasi yang dapat diakses dari Internet melalui cloud dapat dijelaskan sebagai berikut:

1. Node Sensor akan memeriksa kelembaban, Suhu dan $\mathrm{pH}$ tanah dan dikirimkan ke Node Penerima.

2. Node penerima mengolah data dan memberikan keputusan untuk membuka atau menutup kran air apabila Suhu naik, Kelembaban turun atau $\mathrm{pH}$ naik.

3. Kran air akan otomatis terbuka bila memenuhi salah satu dari ketiga kriteria yang ditentukan.

4. Water Flow akan mengukur seberapa banyak air yang sudah disalurkan sesuai dengan prosentase air yang diperbolehkan dari aturan Subak.

5. Node Penerima akan mengirimkan data ke Server database secara berkala dan memberikan informasi ke internet melalui cloud.

6. Status dari kondisi Tanah dan status kran air dapat dimonitor secara langsung dari internet melalui cloud dengan media web browser baik dari PC ataupun Smartphone. Penejelasan secara detail dapat dilihat pada Gambar 9.

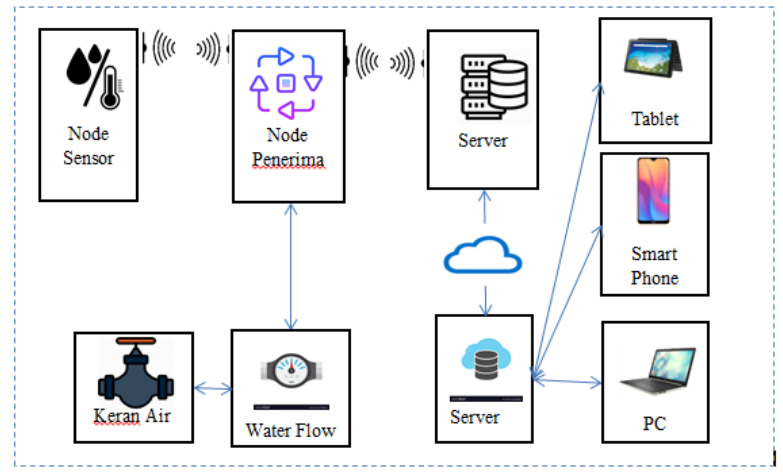

Gambar 9: Diagram Cara kerja Sensor dan Monitoring sistem

Hasil Monitoring dari node sensor di masing-masing lahan menghasilakan data yang akurat yang tersimpan di server database.. Terjadi kenaikan suhu dan penurunan 
kelembaban tanah pada siang hari dengan hasil yang berbeda di masing-masing lahan. Kenaikan suhu tertinggi terjadi mulai jam 13:00WITA sampai jam 15:00WITA yang memicu pengaktipkan aliran air ke lahan pada sensor yang ditempatkan.

Pengaktipkan aliran air pada Selenoid Valve terjadi pada jam yang berbeda-beda di masing-masing hari sangat tergantung dari sinar matahari yang memanasi lahan dan kelembaban tanah. Dalam penelinitan ini suhu yang dibutuhkan untuk mengaktipkan aliran air mulai suhu 36 Derajat Celcius keatas, sedangkan kelembaban tanah akan dipicu mulai dibawah 300, namun khusus untuk $\mathrm{pH}$ tanah yang tidak mengalami perubahan tidak memicu pengaktipan Selenoid Valve.

Perubahan Suhu di Node 3 yang memicu pengaktipkan Selenoid Valve ketiga dalam kondisi ON bagitu juga Selenoid Valve pertama dan kedua masih dalam kondisi ON yang sedang mengalirkan air ke lahan.

Pada saat Node penerima hanya menerima node yang masuk dan Node Sensor tidak ada mengaktipkan keran air maka tidak ada pembagian air yang dilakukan, pada saat ini Node penerima akan terus menerus menunggu sinyal pengaktipan air dari Node sensor. Kondisi Node Sensor pada saat diterima Node Penerima dapat dilihat pada Gambar 9. Pada kondisi ini Sensor hanya menerima sinyal dari Node Sensor saja, dimulai dari 1 buah Node Sensor, 2 buah Node Sensor dan 3 buah Node Sensor tanpa pengaktipan keran.

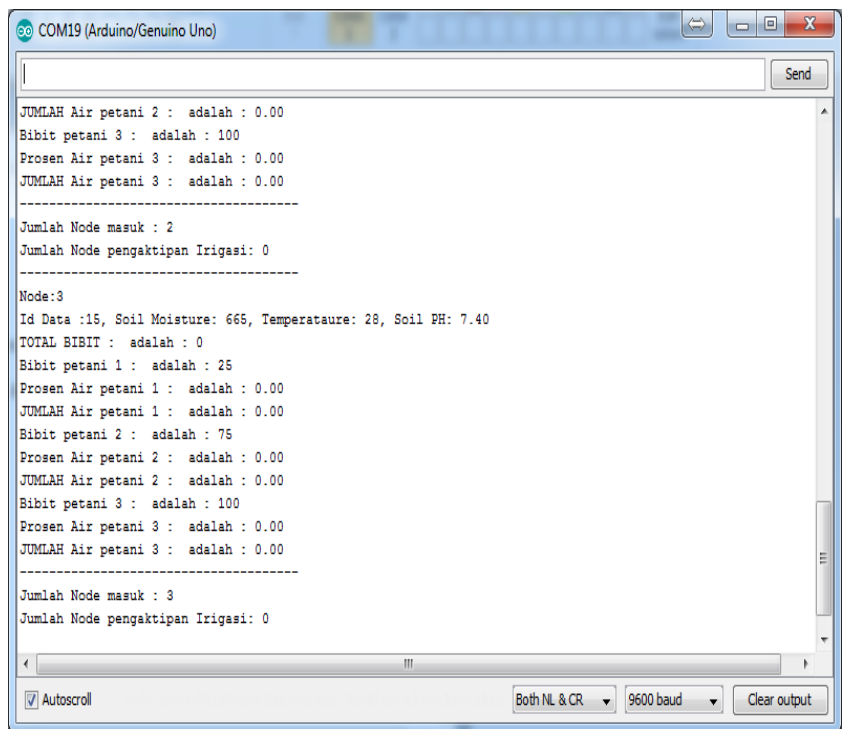

Gambar 10: Kondisi 3 buah node diterima dan tidak mengaktipkan keran

Pada saat kondisi hanya satu Sensor meminta pengaktipan keran, maka hanya 1 lahan yang dialiri air sampai sensor mengirimkan data air sudah cukup dan menghentikan aliran air secara otomatis. Permintaan pengaktipan keran secara berturut-turut hanya 1 pentai meminta pengaktipan keran irigasi dapat dilihat pada Gambar 11 terlihat petani A kondisi meminta pengaktipkan keran.

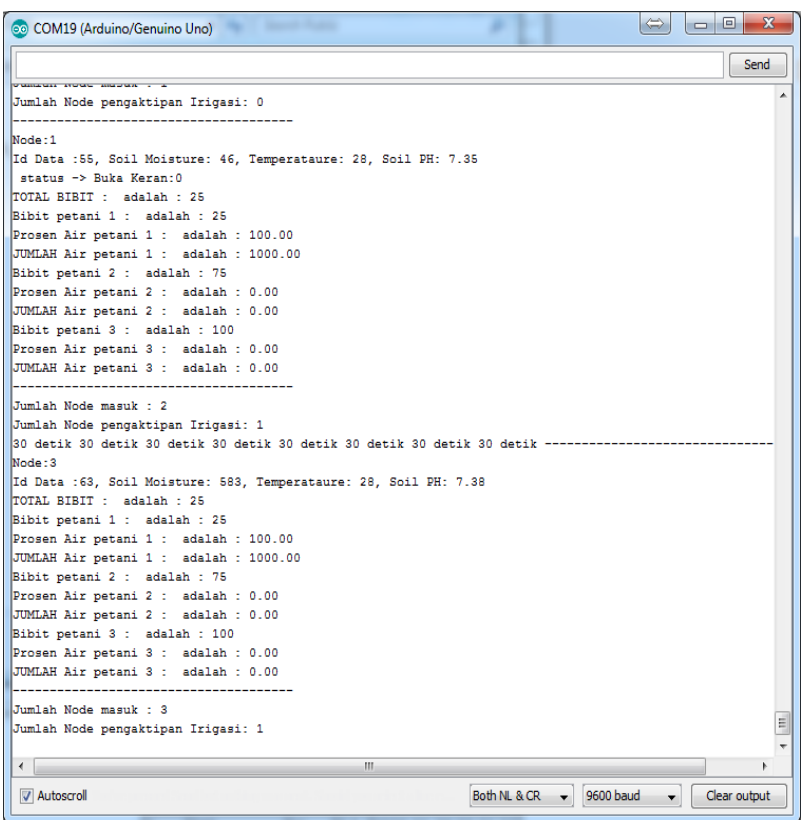

Gambar 11: Kondisi 3 buah node diterima dan 1 node mengaktipkan keran pada petani $\mathrm{A}$

Pada saat kondisi 2 buah Node Sensor aktip seperti Node Sensor A dan Node Sensor B Aktip, Petani A mendapatkan prosentase air sebesar $25 \%$ dengan jumlah air sebesar $250 \mathrm{~mL}$ dan Petani B mendapatkan prosentase air $75 \%$ dengan jumlah air $750 \mathrm{~mL}$ dapat dilihat pada Gambar 12.

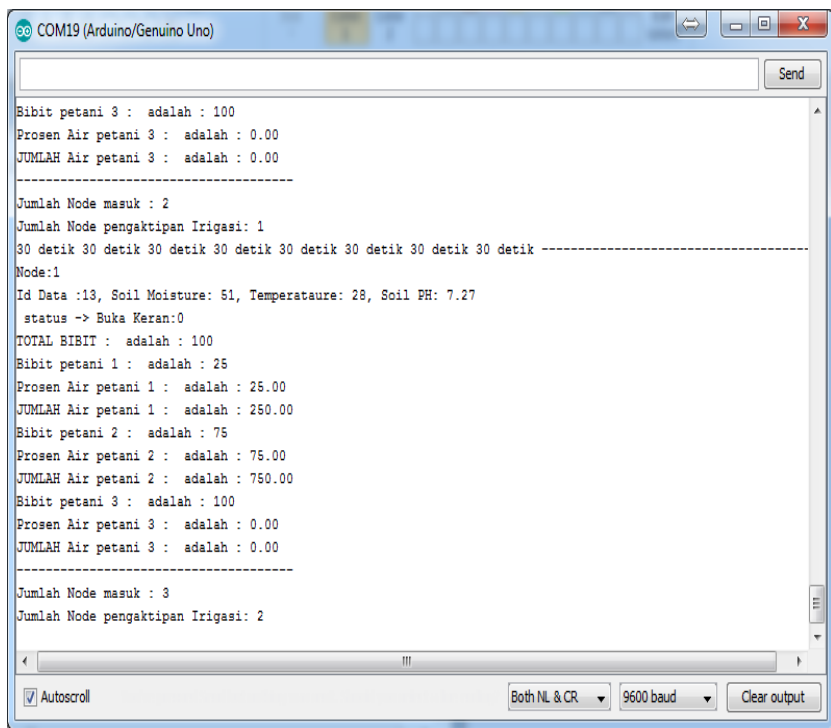

Gambar 12: Kondisi 3 buah node diterima dan 2 buah Node mengaktipkan keran

Pada kondisi Node Sensor B dan C aktip maka prosentase air yang diperoleh sebesar $25 \%$ untuk petani B dengan jumlah air sebesar $428.6 \mathrm{~mL}$ sedangkan petani $\mathrm{C}$ mendapatkan prosentasi air $57.14 \%$ dengan jumlah air sebesar $571.4 \mathrm{~mL}$ dapat dilihat pada Gambar 13. 


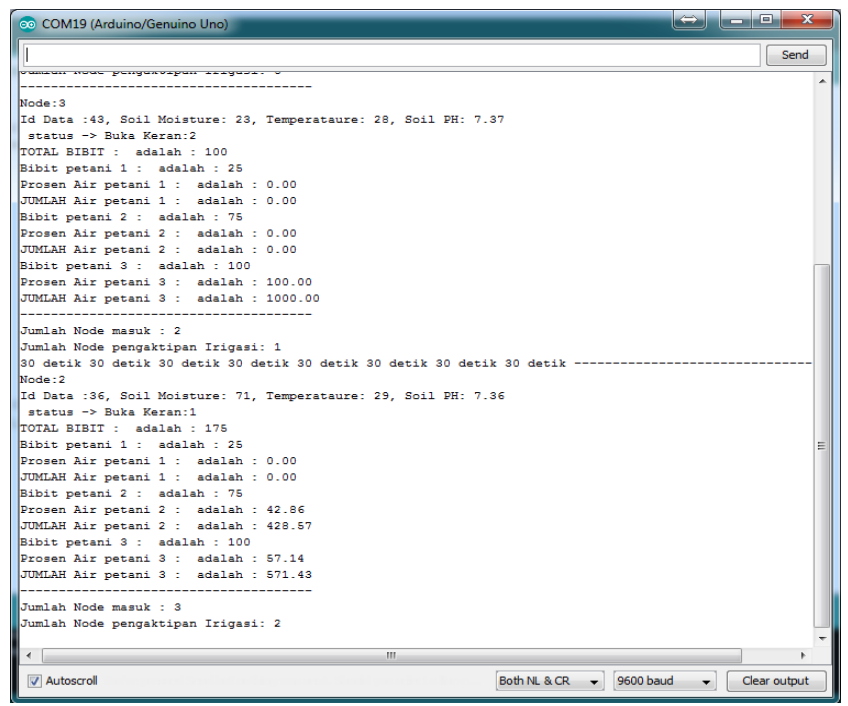

Gambar 13: Kondisi 2 buah node diterima dan 2 buah Node mengaktipkan keran

Pada saat kondisi 2 buah Node Sensor Aktip seperti Node Sensor A dan Node Sensor C aktip maka Petani A mendapatkan prosentase air sebesar $20 \%$ dengan jumlah air sebesar $200 \mathrm{~mL}$ dan Petani C mendapatkan prosentase air sebesar $80 \%$ dengan jumlah air $800 \mathrm{~mL}$ dapat dilihat pada Gambar 14.

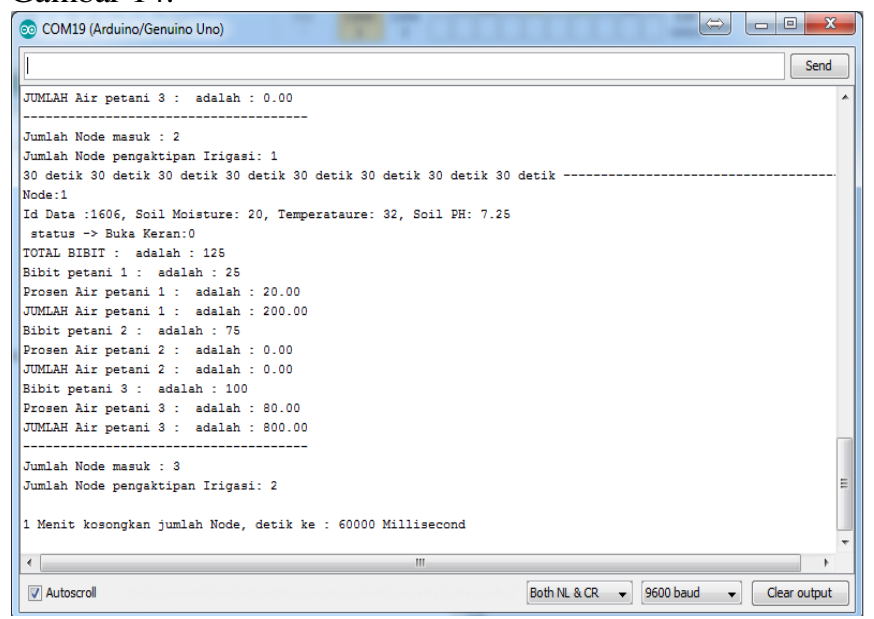

Gambar 14: Kondisi 3 buah node diterima dan 2 node mengaktipkan keran

Pada kondisi 3 buah sensor aktip maka akan menghasilkan pembagian 3 aliran air dengan pembagian masing-masing ke petani A dengan prosentase sebesar $12.50 \%$ dengan jumlah air sebesar $125 \mathrm{~mL}$, Petani B mendapatkan air sebesar $37.50 \%$ dengan jumlah air sebesar $375 \mathrm{~mL}$ dan Petani C mendapatkan air sebesar $50 \%$ dengan jumlah air sebesar $500 \mathrm{~mL}$ dapat dilihat pada Gambar 15.

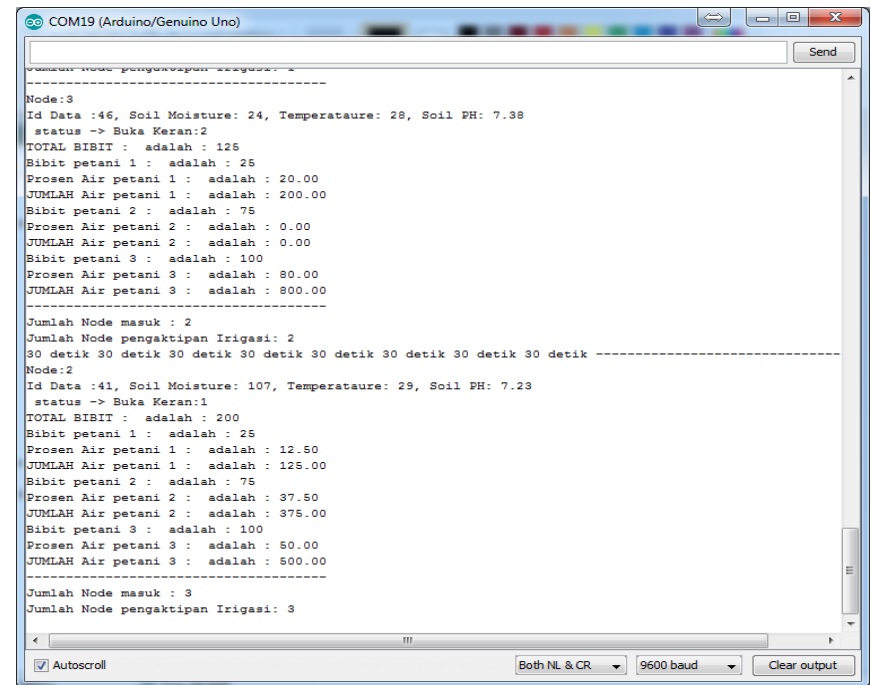

Gambar 15: Kondisi 3 buah node diterima dan 3 Node meminta pengaktipan keran

\section{KESIMPULAN}

Pemanfaatan Teknologi informasi dalam Penerapan penelitian ini sangat tepat dengan pembagian air yang adil dengan prosentase jumlah bibit dari masing-masing petani dan jumlah air yang diperoleh masing-masing petani sesuai dengan aturan Subak di Bali. Penerapan penelitian ini di pengairan Subak di Bali dapat dilakukan dengan melakukan pengembangan ke alat yang lebih besar sehingga dapat digunakan di pengairan dengan debit air yang lebih besar.

\section{REFERENSI}

[1] Ardhana dan IP. Gede, Ekologi Tumbuhan, Udayana University Press, Bali,2012.

[2] Amaru, Kharistya dkk, Kajian Kelembaban Tanah dan Kebutuhan air beberapa Varietas Hibrida DR UNPAD, 2013

[3] Asdak, Chay. (2010). Hidrologi dan Pengelolaan Daerah Aliran Air Sungai: Edisi Revisi Kelima. Yogyakarta: Gadjah Mada University Press Yogyakarta.

[4] Karamina,dkk, Kompleksitas pengaruh temperature dan kelembaban tanah terhadap nilai $\mathrm{pH}$ tanah di perkebunan jambu biji varietas Kristal (psidium guajaval.) Bumiaji, Kota Batu, 2017

[5] Zaenal Abidin,Piscataway, NJ: Institute of Electrical and Electronics Engineers (IEEE), 2017. p. 75-81

[6] Paucar, L. Garcia Paucar dkk, 2015. Decision support for smart Irrigation by Means of Wireless Distribution Sensor.

[7] Youseft dkk, 2017. Smart Irrigation Decision Support based on fuzzy Logic using Wireless Sensor Network.

[8] Bennis, dkk 2015. Drip Irrigation System using wireless Sensor Network

[9] Ananta Wijaya, dkk, 2016. Design Model of Subak Smart Irrigation menggunakan data temperature tanah sebagi model irigasi

[10] Jupri, Ahmad dkk, 2017. Rancang Bangun alat ukur suhu, kelembaban dan $\mathrm{pH}$ pada tanah berbasis Mikrokontroler ATMega328P 